\title{
Pengaruh Perbedaan Konsentrasi Asam Asetat dan Lama Waktu Ekstraksi Kolagen dari Kulit Ikan Situhuk Hitam (Makaira indica)
}

\author{
Raymundus J. Tangka'a ${ }^{1}$, Feny Mentang ${ }^{1 *}$, Agnes T. Agustin ${ }^{1}$ \\ Hens Onibala $^{1}$, Bertie E. Kaseger ${ }^{1}$, Daisy M. Makapedua ${ }^{1}$, Grace Sanger ${ }^{1}$ \\ ${ }^{1}$ Program Studi Teknologi Hasil Perikanan, \\ Fakultas Perikanan dan Ilmu Kelautan, Universitas Sam Ratulangi. \\ Jl. Kampus Unsrat Bahu, Manado 95115, Sulawesi Utara, Indonesia. \\ *Penulis Korespondensi:fmentang@unsrat.ac.id \\ (Diterima 17-12-2019; Direvisi 11-05-2020; Dipublikasi 19-05-2020)
}

\begin{abstract}
This study aims to determine the effect of different concentrations of acetic acid and the time of collagen extraction from the skin of black situhuk fish (Makaira indica). In this study the treatment of $\mathrm{CH}_{3} \mathrm{COOH}$ concentration of $0.7 \mathrm{M}(\mathrm{A} 1), \mathrm{CH}_{3} \mathrm{COOH}$ of $0.9 \mathrm{M}(\mathrm{A} 2)$, extraction time of 24 hours (B1), and 48 hours (B2). The stages of making collagen are; washing \& cutting, soaking $(\mathrm{NaOH})$, washing (up to neutral $\mathrm{pH}$ ), extraction $\left(\mathrm{CH}_{3} \mathrm{COOH}\right)$, precipitation, salting out, centrifuge. The results of this study revealed that the highest yield in the treatment of $\mathrm{CH}_{3} \mathrm{COOH} 0.9 \mathrm{M}$ concentration with a 24-hour extraction time of $4.77 \%$. The lowest water content was obtained from a $0.7 \mathrm{M} \mathrm{CH}_{3} \mathrm{COOH}$ concentration treatment with a 24 hour extraction time that was $14.74 \%$. This is caused by the absorption of air and water molecules in the environment that occur in samples (hygroscopic). The results of $\mathrm{pH}$ stability ranged from 4.6 (treatment of $\mathrm{CH}_{3} \mathrm{COOH} 0.7 \mathrm{M}$ concentration with extraction time 24 hours) - 6.6 (treatment of $\mathrm{CH}_{3} \mathrm{COOH}$ concentration of $0.9 \mathrm{M}$ with extraction time 48 hours), this proves that the length of immersion time affect the acidity level of collagen.
\end{abstract}

Keywords: collagen, Makaira indica, salting out, $\mathrm{CH}_{3} \mathrm{COOH}$.

Penelitian ini bertujuan untuk mengetahui pengaruh perbedaan konsentrasi asam asetat dan lama waktu ekstraksi kolagen dari kulit ikan situhuk hitam (Makaira indica). Pada penelitian ini digunakan perlakuan konsentrasi $\mathrm{CH}_{3} \mathrm{COOH}$ 0,7M (A1) dan $\mathrm{CH}_{3} \mathrm{COOH}$ 0,9M (A2) dan waktu ekstraksi 24 jam (B1) dan 48 jam (B2). Tahapan pembuatan kolagen ini adalah; pencucian \& pemotongan, perendaman $(\mathrm{NaOH})$, pencucian (sampai $\mathrm{pH}$ netral), ekstraksi $\left(\mathrm{CH}_{3} \mathrm{COOH}\right)$, pengendapan, salting out, sentrifuse. Hasil penelitian ini diperoleh rendemen terbanyak ada pada perlakuan konsetrasi $\mathrm{CH}_{3} \mathrm{COOH} 0,9 \mathrm{M}$ dengan lama waktu ekstraksi 24 jam yaitu sebesar $4,77 \%$. Kadar air yang paling rendah diperoleh dari perlakuan konsentrasi $\mathrm{CH}_{3} \mathrm{COOH} 0,7 \mathrm{M}$ dengan lama waktu ekstraksi 24 jam yaitu sebesar 14,74\%. Hal ini diakibatkan karena penyerapan udara dan molekul air di lingkungan yang terjadi pada sampel (hygroscopic). Hasil stabilitas pH berkisar antara 4,6 (perlakuan konsetrasi $\mathrm{CH}_{3} \mathrm{COOH} \mathrm{0,7} \mathrm{M} \mathrm{dengan} \mathrm{lama} \mathrm{waktu} \mathrm{ekstraksi} 24$ jam ) - 6,6 (perlakuan konsentrasi $\mathrm{CH}_{3} \mathrm{COOH}$ 0,9M dengan lama waktu ekstraksi 48 jam), hal ini membuktikan bahwa semakin lama waktu perendaman berpengaruh pada derajat keasaman kolagen yang dihasilkan.

Kata kunci: kolagen, Makaira indica, salting out, $\mathrm{CH}_{3} \mathrm{COOH}$.

\section{PENDAHULUAN}

Indonesia memiliki potensi sumber daya perikanan yang melimpah, namun pemanfaatan selama ini masih sebatas daging (fillet). Produksi perikanan tangkap Indonesia dari subsektor perikanan laut dan perikanan umum pada tahun 2014 mencapai 6,4 juta ton, sehingga diperkirakan potensi limbah perikanan mencapai sekitar 4,1 juta ton (BPS 2014).

Limbah perikanan seperti sisik, kulit dan perut ikan telah diteliti mengandung protein yang tinggi dan apabila dikonversi menjadi turunan protein lain dapat meningkatkan situhuk ekonomis limbah tersebut (Liu et al. 2012; Chen et al. 2016). Kandungan protein yang tinggi diduga berasal dari kandungan protein jaringan ikat yang tidak larut dalam air. Protein jaringan ikat tersebut dapat dikonversi menjadi derivat protein yang lebih sederhana seperti hidrolisat protein, kolagen dan kolagen sehingga dapat meningkatkan situhuk tambah diversifikasi produk hasil samping industri perikanan.

Kolagen merupakan protein utama yang menyusun sekitar $30 \%$ dari total protein pada tubuh hewan (Pati et al, 2010). Menurut Ward dan Court (1977) Kolagen merupakan komponen struktural utama pada serat-serat jaringan pengikat, berwarna putih dan terdapat di dalam semua jaringan dan organ hewan dan berperan penting dalam penyusun bentuk tubuh. 
Kolagen banyak dimanfaatkan dalam berbagai bidang diantaranya dalam industri; pangan, kosmetik, farmasi, kedokteran, fotografi dan sebagainya (Kurniawan 2006). Steven (2012) menjelaskan kolagen yang digunakan umumnya berasal dari hewan daratan, seperti babi dan sapi. Kurniawan (2006) menjelaskan kolagen yang merupakan produk turunan dari kolagen produksinya berasal dari $40 \%$ kolagen babi dan $60 \%$ kolagen sapi.

Penggunaan kolagen yang berasal dari babi sangat meresahkan masyarakat yang beragama Islam, sedangkan kolagen yang berasal dari sapi meresahkan masyarakat yang beragama hindu dan mempunyai potensi terjangkit penyakit Bovine Spongiform Encephalopathy (BSE) (Steven, 2012). Hal ini membuat peneliti harus mencari sumber kolagen alternatif yang berasal dari hewan lain termasuk hewan laut agar dapat diterima semua kalangan masyarakat.

Selama ini kulit ikan dibuang, dijadikan campuran pakan, kerupuk, dan sebagainya. Potensi kolagen pada kulit ikan cukup menjanjikan. Potensi kolagen pada kulit ikan dapat dilihat berdasarkan nilai kuantitas maupun kualitas kolagen yang dihasilkan. Dari nilai kuantitas potensi kolagen dapat dilihat dari rendemen kolagen yang dihasilkan semakin tinggi nilai rendemen kolagen yang dihasilkan maka semakin baik potensinya (Steven, 2012).

Penelitian ini bertujuan untuk mendapatkan kolagen dari kulit ikan situhuk hitam (Makaira indica) serta menghasilkan konsentrasi pelarut yang optimal dalam proses ekstraksi kolagen kulit ikan situhuk hitam. Hasil penelitian ini diharapkan dapat memberikan informasi kepada masyarakat tentang pemanfaatan limbah perikanan seperti kulit ikan situhuk hitam sebagai bahan pembuatan kolagen dan memberikan informasi berupa pentingnya kolagen dalam dunia pangan, industri, farmasi dan kosmetik.

\section{METODE PENELITIAN}

\section{Alat dan Bahan}

Bahan penelitian adalah ikan situhuk hitam yang dibeli dari ... Untuk pengeringan digunakan cabinet dryer. Alat yang digunakan terdiri atas satu unit alat ekstraksi kolagen (toples, beaker gelas $1000 \mathrm{ml}$, cool box, saringan, kain blacu) dan sentrifuse. Alat yang digunakan untuk pengujian $\mathrm{pH}$ meter, oven, timbangan analitik dan alat-alat gelas lainnya. Bahan baku yang digunakan adalah kulit ikan situhuk. Bahan untuk analisa adalah $\mathrm{NaOH}, \mathrm{CH}_{3} \mathrm{COOH}, \mathrm{NaCl}$, akuades.

\section{Preparasi Bahan Baku (modifikasi dari Rahael, 2014)}

Preparasi kulit ikan situhuk hitam dilakukan dengan menghilangkan sisa lemak dan daging serta mencuci bersih menggunakan air mengalir. Tahap selanjutnya yaitu pemotongan kulit menjadi ukuran $1 \times 1 \mathrm{~cm}$. Kemudian dicuci kembali menggunakan air mengalir dan pembilasan terakhir menggunakan akuades.

\section{Pre-treatment (modifikasi dari Rahael, 2014)}

Kulit ikan situhuk hitam yang sudah dipreparasi kemudian ditimbang sebanyak 500 gram dan direndam dalam larutan $\mathrm{NaOH} 0,1 \mathrm{M}$ dengan rasio 1:3 (b/v) selama 24 jam dengan suhu $28^{\circ} \mathrm{C}$. Kulit ikan dinetralisasi dengan akuades dengan suhu $12^{\circ} \mathrm{C}$ hingga mencapai $\mathrm{pH} 7$.

\section{Ekstraksi Kolagen (modifikasi dari Rahael, 2014)}

Sampel yang telah dipretreatment, diekstraksi menggunakan asam asetat $(\mathrm{CH} 3 \mathrm{COOH})$ dengan konsentrasi 0,7 M dan 0,9 $\mathrm{M}$ dengan rasio 1:30 (b/v) selama 24 dan 48 jam. Kemudian disaring untuk mendapat filtrat kolagen. Residu hasil penyaringan di salting out dengan $\mathrm{NaCl} 0,9 \mathrm{M}$ selama 24 . Hasil presipitasi disentrifugasi dengan kecepatan 10.000 rpm selama 25 menit pada suhu $4^{\circ} \mathrm{C}$. Hasil kolagen dikeringkan dengan menggunakan oven pada suhu $50^{\circ} \mathrm{C}$. 


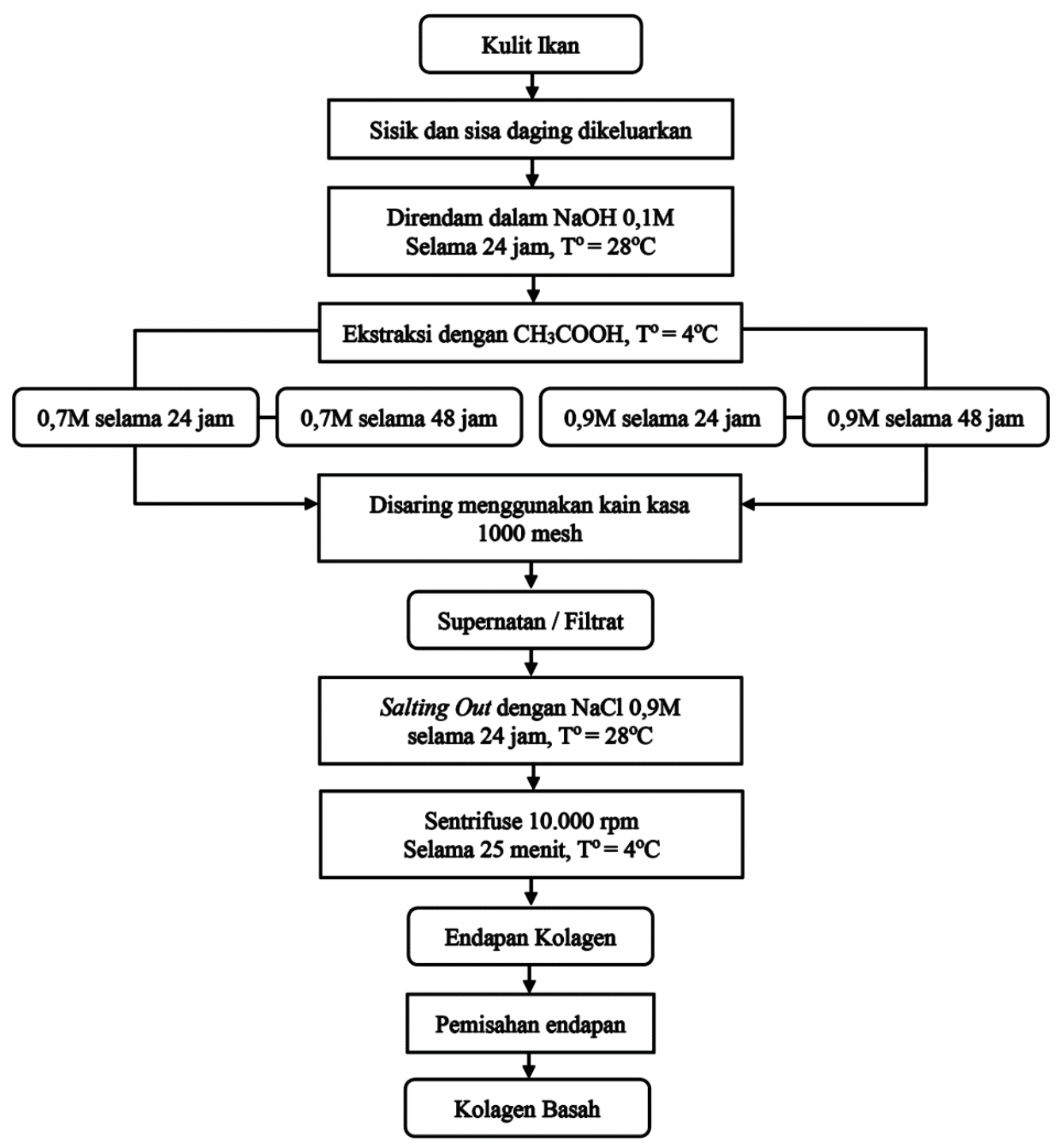

Gambar 1. Prosedur Pembuatan Kolagen

\section{HASIL DAN PEMBAHASAN}

\section{Rendemen (\%)}

Data hasil pengujian nilai rendemen dapat dilihat bahwa nilai total tertinggi rendemen untuk kolagen ikan situhuk hitam yang direndam dalam larutan $\mathrm{CH}_{3} \mathrm{COOH}$ dengan konsentrasi 0,9M dan lama ekstraksi 24 jam adalah 4,77 (A2B1).

Hasil analisis sidik ragam menunjukkan bahwa interaksi perlakuan konsentrasi asam asetat dan waktu ekstraksi tidak berpengaruh nyata $(\mathrm{p}<0,05)$ terhadap produksi rendemen bubuk kolagen pada tingkat signifikansi 95\%. Berdasarkan pengujian, dihasilkan rendemen bubuk kolagen dari sampel kulit ikan situhuk hitam berkisar antara 1,12\%-4,77\%. Persentase rendemen kolagen yang diekstraksi dengan asam asetat konsentrasi $0,70 \mathrm{M}$ dan $0,90 \mathrm{M}$ pada selang waktu dan 24 dan 48 jam diperlihatkan pada Gambar 1. Berdasarkan Gambar 1, terlihat bahwa proses ekstraksi sampel kulit ikan situhuk hitam yang menggunakan konsentrasi asetat $0,9 \mathrm{M}$ (tertinggi) pada waktu 24 jam (terpendek) menghasilkan persentase rendemen kolagen yang lebih besar $(4,77 \%)$ dibandingkan 
waktu ekstraksi yang lama (48 jam), yakni $1,12 \%$. Sama halnya dengan penggunaan asam asetat rendah $(0,7 \mathrm{M})$ selang waktu $48 \mathrm{jam}$, artinya makin tinggi konsentrasi larutan asam asetat yang digunakan, makin banyak kolagen yang dihasilkan. Sebaliknya makin lama waktu ekstraksi makin sedikit dihasilkan. Hal ini menunjukkan bahwa faktor konsentrasi larutan asam asetat memberikan pengaruh signifikan terhadap ekstraksi protein kolagen.

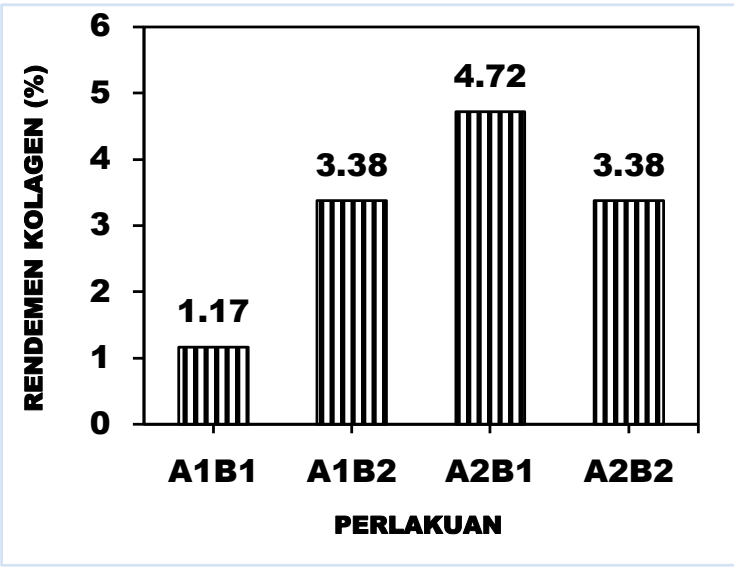

Gambar 2. Histogram rendemen kolagen kulit ikan situhuk hitam.

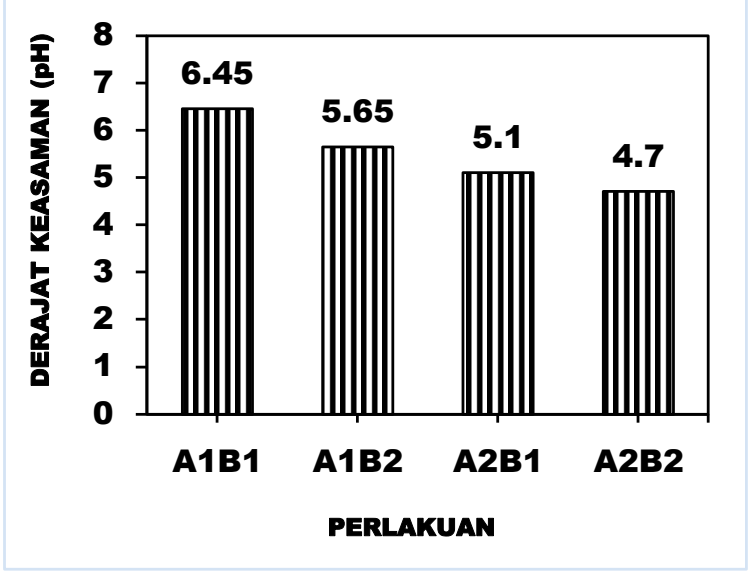

Gambar 3. Histogram pH kolagen kulit ikan situhuk hitam.

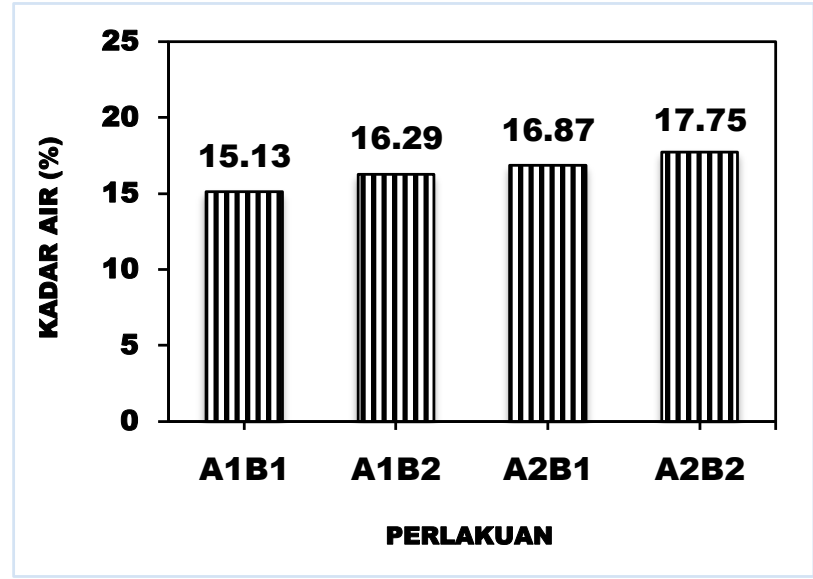

Gambar 4. Histogram kadar air kolagen kulit ikan situhuk hitam



\section{Derajat Keasaman (pH)}

Data hasil pengujian nilai $\mathrm{pH}$ dapat dilihat bahwa nilai total tertinggi $\mathrm{pH}$ untuk kolagen ikan situhuk hitam yang direndam dalam larutan $\mathrm{CH}_{3} \mathrm{COOH}$ dengan konsentrasi $0,7 \mathrm{M}$ dan lama ekstraksi 12 jam adalah 6,6 (A1B1).

Hasil pengukuran $\mathrm{pH}$ kolagen kulit ikan situhuk hitam bersifat asam, yaitu 4,8;4,6 $(0,9 \mathrm{M}$ selama 48 jam), 5,2; 5,0 (0,9M selama 24 jam), 5,7; 5,6 (0,7M selama 48 jam) dan 6,6; 6,3 (0,7M selama $24 \mathrm{jam}$ ), pada suhu ruang. Hasil tersebut lebih rendah dibandingkan dengan syarat mutu kolagen SNI 8076:2014 yaitu 6,5-8, namun sedikit lebih tinggi dari $\mathrm{pH}$ kolagen beberapa merk kolagen untuk kosmetik yang dilaporkan oleh Peng dkk. (2004) yaitu berkisar antara 3,8-4,7. 
Selain itu, perbedaan nilai $\mathrm{pH}$ kolagen tersebut dapat disebabkan oleh perbedaan jenis dan konsentrasi larutan yang digunakan, baik asam atau basa dan proses penetralan. Ko mbinasi proses asam dan basa cenderung menghasilkan $\mathrm{pH}$ mendekati netral (Zhou dan Regenstein, 2005). Proses penetralan yang dilakukan akan berpengaruh pada $\mathrm{pH}$ akhir kolagen, karena selain dapat mengurangi sisa-sisa larutan asam atau basa akibat perendaman, juga kemungkinan dapat ditimbulkan dari air yang digunakan untuk menetralkan kolagen tersebut. Air yang digunakan bersifat kurang mendekati netral, sehingga mengakibatkan nilai $\mathrm{pH}$ akhir kolagen yang dihasilkan kurang mendekati $\mathrm{pH}$ netral.

\section{Kadar Air (\%)}

Data hasil pengujian nilai kadar air dapat dilihat bahwa nilai total tertinggi kadar air untuk kolagen ikan situhuk hitam yang direndam dalam larutan $\mathrm{CO}_{3} \mathrm{COOH}$ dengan konsentrasi $0,9 \mathrm{M}$ dan lama ekstraksi 24 jam adalah 17,83 (A2B2). Pada kedua sampel kolagen kulit ikan menunjukkan nilai kadar air yang sangat tinggi jika dibandingkan dengan syarat mutu kolagen BSN (2004). Kadar air yang dihasilkan yaitu berkisar $14,74 \%-17,83 \%$, hal ini diduga bahwa terjadinya perubahan wujud sampel dari padatan kering menjadi cair.

Perubahan wujud ini disebabkan oleh penyerapan udara dan molekul air di lingkungan yang terjadi pada sampel tersebut atau biasa disebut peristiwa hygroscopic. Air merupakan salah satu unsur terpenting pada makanan. Kadar air adalah komponen dalam bahan makanan yang mempengaruhi tampilan, tekstur dan cita rasa. Semakin tinggi kadar air pada makanan maka tekstur semakin lunak sebaliknya jika kadar air dalam bahan pangan sedikit maka akan semakin keras (Winarno, 2004). Kadar air di dalam kolagen akan berpengaruh terhadap daya simpan, karena kadar air erat kaitannya dengan aktivitas metabolisme yang terjadi selama kolagen tersebut disimpan seperti aktivitas enzim, aktivitas mikroba dan aktivitas kimiawi yaitu terjadi ketengikan dan reaksi-reaksi non enzimatik sehingga menimbulkan perubahan sifat-sifat organoleptik dan nilai mutunya. Semakin tinggi kadar air di dalam kolagen maka lama umur kolagen semakin rendah namun sebaliknya apabila kadar air rendah maka umur simpan kolagen semakin lama (Noorman, 2016).

\section{KESIMPULAN}

Melalui ekstraksi kolagen dari kulit ikan Situhuk hitam (Makaira indica) dengan perlakukan konsentrasi dan lama waktu ekstraksi dapat diperoleh data sebagai berikut rata-rata rendemen berkisar $1,17-4,72 \%, \mathrm{pH} 4,7-6,45$ dan kadar air 15,13 - 17,75\%. Perlakuan konsentrasi asam asetat yang optimal didapatkan pada sampel A2B1 (perlakuan konsentrasi asam asetat 0,9 M dengan lama waktu ekstraksi 24 jam) menghasilkan rendemen kolagen tertinggi 4,72\%. pH optimal dihasilkan pada sampel A1B1 (perlakuan konsentrasi asam asetat $0,7 \mathrm{M}$ dengan lama waktu ekstraksi 24 jam) yaitu 6,45, hal ini sesuai dengan standar mutu $\mathrm{pH}$ kolagen $(6,5-8)$. Kadar air optimal dihasilkan pada sampel A1B1 (perlakuan konsentrasi asam asetat $0,7 \mathrm{M}$ dengan lama waktu ekstraksi 24 jam) yaitu 15,13. Dari penelitian yang dilaksanakan maka perlu adanya penelitian lanjutan tentang karakteristik kolagen ikan situhuk yang dihasilkan, pengaplikasian kolagen kulit ikan situhuk pada bidang biomedis, farmasi dan kosmetik dan perlu adanya ekstraksi kolagen dengan suhu tinggi sebagai bahan pembanding terhadap kolagen yang dihasilkan.

\section{DAFTAR PUSTAKA}

[BPS] Badan Pusat Statistik (2016). Produksi Perikanan Menurut Subsektor (ribu ton), 1999-2014. Jakarta : Badan Pusat Statistik.

[BSN] Badan Standarisasi Nasional (2014). Standar Nasional Indonesia Tentang Kolagen Kasar Dari Sisik Ikan. Jakarta : Badan Standarisasi Nasional.

Kurniawan, T. (2006). Aplikasi Kolagen Tulang Ikan Kakap Merah (Lutjanus sp) pada Pembuatan Permen Jelly. Skripsi, Institut Pertanian Bogor.

Liu D, Liang L, Regenstein JM, Zhou P. (2012). Extraction and characterization of pepsin-solubilised collagen from fins, scales, skins, bones and swim bladders of bighead carp (Hypophthalmichthys nobilis). Food Chemistry, 133: 14411448 . 
Noorman, T. A. (2016). Perbandingan Produksi Kolagen Dari Sisik dan Tulang Ikan Gurami (Osphronemus gouramy) Secara Kimia dan Enzimatis. Artikel Ilmiah, 15:9-10.

Pati 2010 - Pati F, Adhikari B, Dhara S. (2010). Isolation and characterization of fish scale collagen of higher thermal stability. Bioresource Technology, 101(10): 3737-3742.

Rahael, K. (2014). Karakteristik Organoleptik Tekstur Stik Ikan Asap yang Dicoating dengan penambahan Miofibril dan Kolagen Ikan Situhuk Hitam (Makaira indica). Jurnal Media Teknologi Hasil Perikanan UNSRAT, 11:2-4.

Setiawan, L. (2007). Pembuatan Asam Asetat dengan Cara Murni. Jakarta.

Steven, (2012). Isolasi dan Karakterisasi Kolagen Larut Asam dari Kulit Ikan Lele Dumbo (Clarias gariepinus). Teknologi Hasil Perairan. Fakultas Perikanan dan Ilmu Kelautan. Skripsi, Institut Pertanian Bogor.

Ward, A. G. and Courts. (1977). The Science and Technology of Kolagen. New York : Academic Press.

Winarno, F.G. (2004). Kimia Pangan dan Gizi. Jakarta : Gramedia Pustaka Utama.

Zhou P, Regenstein JM. (2005). Effects of Alkaline and Acid Pretreatments on Alaska Pollock Skin Gelatin Extraction. Journal of Food Science. 70(6): 392-396. 